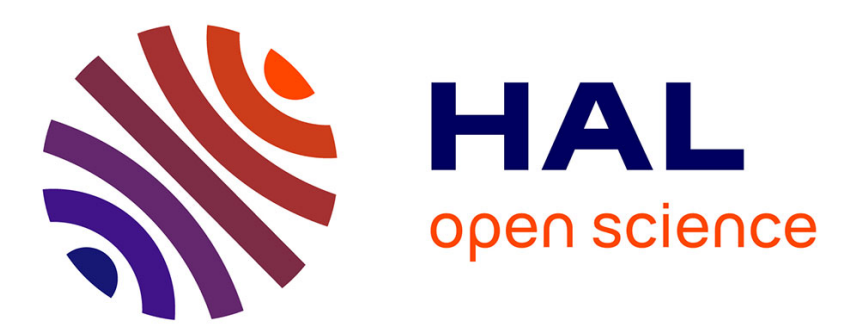

\title{
Three new iridolactone derivatives from the whole plant of Brillantaisia owariensis P. Beauv
}

Perrin Lanversin Foning Tebou, David Ngnokam, Dominique Harakat, Laurence Voutquenne-Nazabadioko

\section{To cite this version:}

Perrin Lanversin Foning Tebou, David Ngnokam, Dominique Harakat, Laurence VoutquenneNazabadioko. Three new iridolactone derivatives from the whole plant of Brillantaisia owariensis P. Beauv. Phytochemistry Letters, 2018, 25, pp.171-174. 10.1016/j.phytol.2018.04.015 . hal-01996239

\section{HAL Id: hal-01996239 \\ https://hal.univ-reims.fr/hal-01996239}

Submitted on 8 Nov 2021

HAL is a multi-disciplinary open access archive for the deposit and dissemination of scientific research documents, whether they are published or not. The documents may come from teaching and research institutions in France or abroad, or from public or private research centers.
L'archive ouverte pluridisciplinaire HAL, est destinée au dépôt et à la diffusion de documents scientifiques de niveau recherche, publiés ou non, émanant des établissements d'enseignement et de recherche français ou étrangers, des laboratoires publics ou privés. 


\section{Three new iridolactone derivatives from the whole plant of Brillantaisia owariensis P. Beauv}

Perrin Lanversin FONING TEBOU ${ }^{\mathrm{a}}$, David NGNOKAM ${ }^{\mathrm{a}}$, Dominique HARAKAT ${ }^{\mathrm{b}}$ and Laurence VOUTQUENNE-NAZABADIOKO ${ }^{c}$

${ }^{\mathrm{a}}$ Faculty of Science, Department of Chemistry, University of Dschang, P.O. Box 67. Dschang Cameroon

bervice Commun d'Analyses, Institut de Chimie Moléculaire de Reims (ICMR), CNRS UMR 7312, Bat. 18 B.P.1039, 51687 Reims Cedex2, France

${ }^{\mathrm{c}}$ Groupe Isolement et Structure, Institut de Chimie Moléculaire de Reims (ICMR), CNRS UMR 7312, Bat. 18 B.P.1039, 51687 Reims Cedex2, France

*Corresponding author. E-mail: dngnokam@yahoo.fr/ngnokam@univ-dschang.org

\section{Corresponding authors:}

* Professor David Ngnokam, Laboratory of Environmental and Applied Chemistry, Department of Chemistry, Faculty of Science, University of Dschang, P.O. Box 67, Dschang, Cameroon, Tel: +237 696710 992. E-mail: dngnokam@yahoo.fr/ngnokam@univ-dschang.org 


\begin{abstract}
Owariensisone B-D, three new lactone iridoids, identified as lactone of $\alpha$-(3-acetoxymethyl-2hydromethylcyclopent-3-en-yl) ethanoic acid (1), lactone of $\alpha$-(4- $\beta$-acetoxy-3- $\beta$ acetoxymethyl-2-hydromethyl-3-hydroxycyclopentyl) ethanoic acid (2) and lactone of $\alpha$-(4- $\beta$ acetoxy-3- $\alpha$-acetoxymethyl-2-hydromethyl-3-hydroxycyclopentyl) ethanoic acid (3) were isolated from the $n$-hexane extract of the whole plant of Brillantaisia owariensis. Their structures were established by interpretation of their spectral data, mainly HR-TOFESIMS, 1D-NMR $\left({ }^{1} \mathrm{H},{ }^{13} \mathrm{C}\right)$ and 2D-NMR $\left({ }^{1} \mathrm{H}-{ }^{1} \mathrm{H}\right.$ COSY, HSQC, HMBC and ROESY) and by comparison with the literature data.
\end{abstract}

Keywords: Brillantaisia owariensis, Acanthaceae, Lactone iridoids, Owariensisone.

\title{
Introduction
}

The genus Brillantaisia belongs to the family Acanthaceae and is found growing throughout tropical Africa and Madagascar and occupies a prominent position in traditional medicine (Ngbolua et al., 2013). Eleven species are known in Cameroon, and among these, Brillantaisia owariensis P. Beauv (Synonym Brillantaisia patula T. Anderson), a large erect shrub with a purple-blue flowers (Heine, 1963). It is found growing in Nigeria, Togo, West Cameroon and across Uganda and Angola. The leaves are used for the treatment of anaemia (Ngbolua et al., 2013), rheumatism, menstrual pain, stomach ache and for their antiplasmodial and analgesic potentials (Asai et al., 2012; Makambila-Koubemba et al., 2011; Mbatchi et al., 2006). Previous study indicated that the alcoholic extract has antibacterial and antioxidant activities (Aluko et al., 2014; Faparusi et al., 2012,) but the phytochemical investigation were limited. Our previous contribution reported the isolation of one new lactone iridoid in the methanol extract with flavonoid and glycosides (Foning Tebou et al., 2016). In an extension of our studies, the $n$-hexane soluble part of the methanol extract of the whole plant of $B$. owariensis was examined in greater detail and three novel lactone iridoids (1-3) were isolated in minor concentration.

\section{Results and discussion}

Purification of the $n$-hexane soluble fraction of the crude $\mathrm{MeOH}$ extract afforded three new compounds, owariensisone B, C and D (1-3) (Fig. 1).

Compound 1 was obtained as yellowish gum. Its molecular formula was determined as $\mathrm{C}_{11} \mathrm{H}_{14} \mathrm{O}_{5}$ on the basis of its HR-TOFESIMS spectrum, exhibiting a pseudo-molecular ion 
peak at $m / z 249.0734[\mathrm{M}+\mathrm{Na}]^{+}\left(\right.$calcd. for $\mathrm{C}_{11} \mathrm{H}_{14} \mathrm{O}_{5} \mathrm{Na}$. 249.0739) with five degrees of unsaturation. Its ${ }^{1} \mathrm{H}-\mathrm{NMR}$ spectrum (Table 1$)$ shows one olefinic proton at $\delta_{\mathrm{H}} 5.83$ (H-7, brqt, $J=1.6 \mathrm{~Hz})$, two pairs of gem-coupled methylene protons at $\delta_{\mathrm{H}} 2.60$ and $2.65(\mathrm{H}-6 \alpha$ and $\mathrm{H}-$ $6 \beta)$, and at $\delta_{\mathrm{H}} 2.80$ and $2.83(\mathrm{H}-4 \alpha$ and $\mathrm{H}-4 \beta$, each $\mathrm{d}, J=14.6 \mathrm{~Hz})$, two pairs of oxymethylene protons at $\delta_{\mathrm{H}} 4.59$ and $4.72(\mathrm{H}-10 \alpha$ and $\mathrm{H}-10 \beta$, each $\mathrm{d}, J=13.2 \mathrm{~Hz})$ and $\delta_{\mathrm{H}} 4.26$ and $4.58(\mathrm{H}-$ $1 \alpha$ and $\mathrm{H}-1 \beta)$, and one methine proton at $\delta_{\mathrm{H}} 2.99(\mathrm{H}-9, \mathrm{dd}, J=6.5,4.9 \mathrm{~Hz})$ attributed to the boschnialactone type skeleton (Sakan et al., 1967; Sisido et al., 1968; Callant et al., 1983; Tanaka et al., 1993; Hilgraf et al., 2012). The signal observed at $\delta_{\mathrm{H}} 2.09$ (3H, H-2', s) indicated the presence of an acetyl group in this compound. This was supported by the ${ }^{13} \mathrm{C}$ NMR spectrum exhibiting eleven carbon signals including two ester carbonyls at $\delta_{\mathrm{C}} 174.4(\mathrm{C}-$ $3)$ and $172.4\left(\mathrm{C}-1^{\prime}\right)$, an acetoxymethyl carbon at $\delta_{\mathrm{C}} 20.7$ (C-2'), two ethylenic carbons at $\delta_{\mathrm{C}}$ $136.7(\mathrm{C}-8)$ and $131.1(\mathrm{C}-7)$, four methylene carbons at $\delta_{\mathrm{C}} 68.4(\mathrm{C}-1), 62.5(\mathrm{C}-10), 48.9(\mathrm{C}-6)$ and $44.4(\mathrm{C}-4)$, one methine carbon at $\delta_{\mathrm{C}} 55.4(\mathrm{C}-9)$ and one quaternary carbon at $\delta_{\mathrm{C}} 78.9(\mathrm{C}-$ 5) bearing an hydroxy group. These NMR data are very closed to owariensisone except for a supplementary acetyl group in C-10 position (Foning Tebou et al., 2016). The ${ }^{1} J_{\mathrm{C}-\mathrm{H}}$ correlation in the HSQC spectrum allowed us to attribute to each carbon the corresponding proton. Thus, the two methylene protons at $\delta_{\mathrm{H}} 2.60$ and $2.65(\mathrm{H}-6)$ were linked to carbon C-6 and those at $\delta_{\mathrm{H}} 2.80$ and $2.83(\mathrm{H}-4)$ were correlated to carbone $\mathrm{C}-4$, and the two pairs oxymethylene protons group at $\delta_{\mathrm{H}} 4.26$ and $4.58(\mathrm{H}-1)$ and 4.59 and $4.72(\mathrm{H}-10)$ were linked to carbon $\mathrm{C}-1$ and $\mathrm{C}-10$, respectively. In the COSY spectrum, protons at $\delta_{\mathrm{H}} 2.60$ and $2.65(\mathrm{H}-$ 6) were correlated with proton at $\delta_{\mathrm{H}} 5.83(\mathrm{H}-7)$. Mains correlations were also observed between the protons at $\delta_{\mathrm{H}} 4.26$ and $4.58(\mathrm{H}-1)$ and proton at $\delta_{\mathrm{H}} 2.99(\mathrm{H}-9)$.

The two gem-methylene systems H-1 and H-4 were allocated to the $\delta$-lactone group by the HMBC cross peaks with the carbonyl carbon at $\delta_{\mathrm{C}} 174.4$ thus confirming its C-3 position. From the HMBC spectrum, correlations observed between the methylene protons $\mathrm{H}-10$ and carbons C-7, C-8 and C-9 suggested that this oxymethylene was located at C-8. The carbonyl of the methyl ester at 172.4 (C-1') was assigned to C-10 by long-range correlation between protons at $\delta_{\mathrm{H}} 2.09\left(\mathrm{H}_{3}-2^{\prime}\right)$ and carbon at $\delta_{\mathrm{C}} 62.5(\mathrm{C}-10)$.

The $\beta$-orientation of hydrogen at C-9 and hydroxyl group at C-5 was supported by the biosynthetic pathway to iridomyrmercin, isoiridomyrmercin and owariensisone, respectively (Lunn, 1961; Foning Tebou et al., 2016), as in usual iridoids. This is confirmed by the coupling constants of $\mathrm{H}-9$ from 6.5 and $4.9 \mathrm{~Hz}$ with both protons $\mathrm{H}-1$, characteristic of pseudo-axial-axial and pseudo-axial-equatorial system as in owariensisone. On the basis of afore mentioned information, the structure of compound 1 was elucidated as $10-O$-acetyl 
owariensisone or lactone of $\alpha$-(3-acetoxymethyl-2-hydromethylcyclopent-3-en-yl) ethanoic acid named owariensisone B (Fig. 1).

Compound 2 was obtained as yellowish gum. Its molecular formula was determined as $\mathrm{C}_{13} \mathrm{H}_{18} \mathrm{O}_{8}$ on the basis of its pseudo-molecular ion peak at $\mathrm{m} / z 325.0905[\mathrm{M}+\mathrm{Na}]^{+}$(calcd. for $\mathrm{C}_{13} \mathrm{H}_{18} \mathrm{O}_{8} \mathrm{Na} 325.0899$ ) in the HR-TOFESIMS spectrum, with five degrees of unsaturation. The ${ }^{1} \mathrm{H}-\mathrm{NMR}$ spectrum (Table 1) shows signals for two acetyl groups [ $\delta_{\mathrm{H}} 2.09(3 \mathrm{H}, \mathrm{H}-2$ ', s), 2.07 (3H, H-2'’, s); $\delta_{\mathrm{C}} 172.5$ (C-1'), 171.8 (C-1'’), 20.7 (C-2'), 21.0 (C-2'’)] and signals of iridoid lactone: two pairs of methylene protons at $\delta_{\mathrm{H}} 2.00$ and $2.43(\mathrm{H}-6 \alpha, \mathrm{dd}, J=14.9,1.8 \mathrm{~Hz}$ and $\mathrm{H}-6 \beta$, dd, $J=14.9,5.0 \mathrm{~Hz})$ and $\delta_{\mathrm{H}} 2.73$ and $2.85(\mathrm{H}-4 \alpha$, dd, $J=14.8,0.8 \mathrm{~Hz}$ and $\mathrm{H}-4 \beta, \mathrm{d}$, $J=14.8 \mathrm{~Hz}$ ), two pairs of oxymethylene protons at $\delta_{\mathrm{H}} 4.49$ and $4.53(\mathrm{H}-1 \alpha$, dd, $J=11.9,7.7$ $\mathrm{Hz}$ and $\mathrm{H}-1 \beta$, dd, $J=11.9,10.0 \mathrm{~Hz})$ and $\delta_{\mathrm{H}} 4.12$ and $4.38(\mathrm{H}-10 \alpha, \mathrm{d}, J=11.6 \mathrm{~Hz}$ and $\mathrm{H}-10 \beta$, $\mathrm{d}, J=11.6 \mathrm{~Hz})$, one methine proton at $\delta_{\mathrm{H}} 2.57(\mathrm{H}-9, \mathrm{dd}, J=10.0,7.7 \mathrm{~Hz})$ and one oxymethine proton at $\delta_{\mathrm{H}} 5.07(\mathrm{H}-7, \mathrm{dd}, J=5.0,1.8 \mathrm{~Hz})$. This was supported by the ${ }^{13} \mathrm{C}-\mathrm{NMR}$ spectrum exhibiting signals of an ester carbonyl at $\delta_{\mathrm{C}} 174.6(\mathrm{C}-3)$, four methylene carbons at $\delta_{\mathrm{C}} 66.6(\mathrm{C}$ 1), $67.4(\mathrm{C}-10), 45.3(\mathrm{C}-6)$ and $44.9(\mathrm{C}-4)$, two methine carbons at $\delta_{\mathrm{C}} 80.9(\mathrm{C}-7)$ and $51.9(\mathrm{C}-$ 9) and two quaternary carbons at $\delta_{\mathrm{C}} 82.1(\mathrm{C}-8)$ and 80.1 (C-5) bearing each an hydroxy group (Table 1). Their attributions were assigned by analysis of COSY and ${ }^{1} J_{\mathrm{C}-\mathrm{H}} \mathrm{HSQC}$ spectra. In the COSY spectrum, proton at $\delta_{\mathrm{H}} 5.07(\mathrm{H}-7)$ was correlated with protons at $\delta_{\mathrm{H}} 2.00$ and 2.43 (H-6). Another correlation was also observed between the protons at $\delta_{\mathrm{H}} 4.49$ and $4.53(\mathrm{H}-1)$ and proton at $\delta_{\mathrm{H}} 2.57(\mathrm{H}-9)$. As compared to compound 1, the ethylenic group in $\Delta_{7,8}$ was replaced by two oxycarbones at C-7 and C-8 as in patriscabrol (Kouna et al., 1994).

Analysis of HMBC spectrum showed correlations between the protons at $\delta_{\mathrm{H}} 4.12$ and $4.38(\mathrm{H}-$ $10)$ and carbons at $\delta_{\mathrm{C}} 82.1(\mathrm{C}-8), 80.9(\mathrm{C}-7)$ and $67.4(\mathrm{C}-9)$ suggesting that this oxymethylene was located at C-8 as in 1.The carbonyl of the methyl ester at 172.5 (C-1') was assigned to C10 by long-range correlation with protons $\mathrm{H}-10$, while the one at 171.8 (C-1',) was linked to C-7 by the long-range correlation with proton at $\delta_{\mathrm{H}} 5.07(\mathrm{H}-7)$. The position of the lactone at $\delta_{\mathrm{C}} 174.6$ was determined as in $\mathbf{1}$. The $\beta$-orientation of $\mathrm{H}-9$ was deduced from the coupling constant of 10.0 and $7.7 \mathrm{~Hz}$ with protons $\mathrm{H}-1 \alpha$-axial and $\mathrm{H}-1 \beta$-equatorial, respectively. The $\alpha$-equatorial orientation of $\mathrm{H}-7$ was deduced from the coupling constant of 5.0 and $1.8 \mathrm{~Hz}$ with H-6 $\alpha$-axial and H-6 $\beta$-equatorial, respectively as observed for similar protons in jioglutoside (Morota et al., 1989) and patriscabrol (Kouna et al., 1994). Thus, the hydroxyl at $\mathrm{C}-7$ is $\beta$-oriented. As observed in jioglutolide the $\delta$-lactone ring has a boat conformation (1B4) (Morota et al., 1989), as observed by the ROESY correlations between H-1 and H-4 $\alpha$ axial. Correlations observed in the ROESY spectrum between $\mathrm{H}-9$ and $\mathrm{H}-10 \beta$, indicated a $\beta$ - 
orientation for C-10 and an $\alpha$-orientation of hydroxyl at C-8 position (Fig. 2). On the basis of afore mentioned information, the structure of compound 2 was elucidated as lactone of $\alpha$-(4$\beta$-acetoxy-3- $\beta$-acetoxymethyl-2-hydromethyl-3-hydroxycyclopentyl) ethanoic acid named owariensisone $\mathbf{C}$ (Fig.1).

Compound $\mathbf{3}$ was obtained as yellowish gum. It has the same molecular formula $\mathrm{C}_{13} \mathrm{H}_{18} \mathrm{O}_{8}$ as compound 2 , and differs from the latter only by the orientation of C-8 oxymethylene. Its ${ }^{1} \mathrm{H}-\mathrm{NMR}$ spectrum (Table 1) was so closed to that of $\mathbf{2}$ and its ${ }^{13} \mathrm{C}-\mathrm{NMR}$ spectrum is almost superimposable on that of $\mathbf{2}$, except for the signal of oxymethylene C-10 $\delta_{\mathrm{C}} 65.0(\Delta-2.4 \mathrm{ppm})$ and methine C-9 $\delta_{\mathrm{C}} 54.0(\Delta+2.1 \mathrm{ppm})$. From the analysis of HMBC spectrum, the oxymethylene, the carbonyl of the methyl ester and the position of the lactone have been solved as in 2. The absence of correlation between H-10 and H-9 in the ROESY spectrum indicated the $\alpha$ orientation of C-10 (Fig.2). On the basis of afore mentioned information, the structure of compound 3 was elucidated as lactone of $\alpha$-(4- $\beta$-acetoxy-3- $\alpha-$ acetoxymethyl-2-hydromethyl-3-hydroxycyclopentyl) ethanoic acid named owariensisone D (Fig.1).

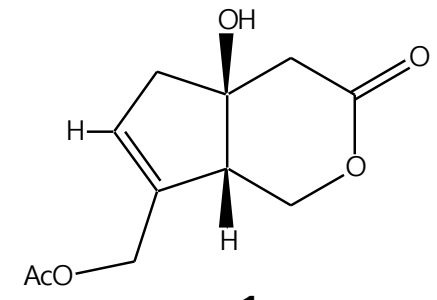

1

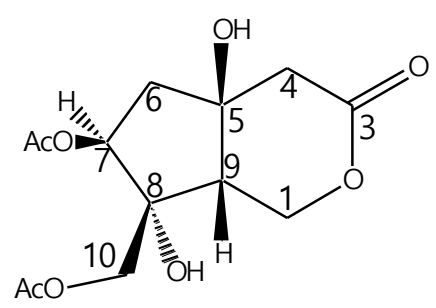

2

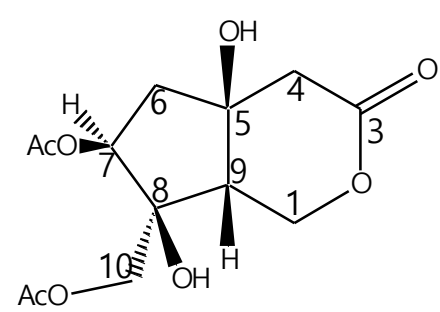

3

Fig.1. Structures of compounds 1-3 isolated from the $n$-hexane soluble extract of Brillantaisia owariensis.

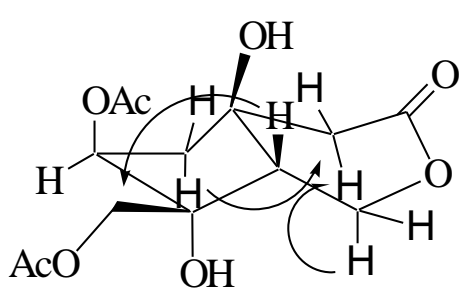

2

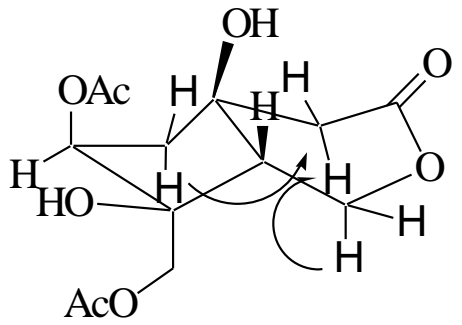

3

Fig.2. Noesy effects in compounds 2-3 
Table 1: ${ }^{1} \mathrm{H}-\mathrm{NMR}(600 \mathrm{MHz})$ and ${ }^{13} \mathrm{C}-\mathrm{NMR}(150 \mathrm{MHz})$ data of compounds $\mathbf{1 - 3}$ in $\mathrm{CD}_{3} \mathrm{OD}$.

\begin{tabular}{lllllll}
\hline $\mathrm{N}^{\circ}$ & \multicolumn{1}{c}{$\mathbf{1}$} & \multicolumn{1}{c}{$\mathbf{2}$} & \multicolumn{1}{c}{$\mathbf{3}$} \\
\hline & ${ }^{13} \mathrm{C}$ & ${ }^{1} \mathrm{H}(\mathrm{J}$ in Hz$)$ & ${ }^{13} \mathrm{C}$ & ${ }^{1} \mathrm{H}(\mathrm{J}$ in $\mathrm{Hz})$ & ${ }^{13} \mathrm{C}$ & ${ }^{1} \mathrm{H}(J \mathrm{in} \mathrm{Hz})$ \\
\cline { 2 - 7 } $\mathbf{1}$ & 68.4 & $4.26(1 \mathrm{H}, \mathrm{dd}, 11.9,6.5)$ & 66.6 & $4.49(1 \mathrm{H}, \mathrm{dd}, 11.9,7.7)$ & 66.9 & $4.21(1 \mathrm{H}, \mathrm{t}, 11.2)$ \\
& & $4.58(1 \mathrm{H}, \mathrm{dd}, 11.9,4.9)$ & & $4.53(1 \mathrm{H}, \mathrm{dd}, 11.9,10.0)$ & & $4.57(1 \mathrm{H}, \mathrm{dd}, 11.6,6.2)$ \\
$\mathbf{3}$ & 174.4 & & 174.6 & & 174.5 & \\
$\mathbf{4}$ & 44.4 & $2.80(1 \mathrm{H}, \mathrm{d}, 14.6)$ & 44.9 & $2.73(1 \mathrm{H}, \mathrm{dd}, 14.8,0.8)$ & 44.7 & $2.57(1 \mathrm{H}, \mathrm{d}, 15.1)$ \\
& & $2.83(1 \mathrm{H}, \mathrm{d}, 14.6)$ & & $2.85(1 \mathrm{H}, \mathrm{d}, 14.8)$ & & $2.78(1 \mathrm{H}, \mathrm{d}, 15.1)$ \\
$\mathbf{5}$ & 78.9 & & 80.1 & & 80.4 & \\
$\mathbf{6}$ & 48.9 & $2.60(1 \mathrm{H}, \mathrm{dq}, 18.1,1.0)$ & 45.3 & $2.00(1 \mathrm{H}, \mathrm{dd}, 14.9,1.8)$ & 46.1 & $1.91(1 \mathrm{H}, \mathrm{dd}, 14.5,1.6)$ \\
& & $2.65(1 \mathrm{H}, \mathrm{dm}, 18.1)$ & & $2.43(1 \mathrm{H}, \mathrm{dd}, 14.9,5.0)$ & & $2.46(1 \mathrm{H}, \mathrm{dd}, 14.5,5.0)$ \\
$\mathbf{7}$ & 131.1 & $5.83(1 \mathrm{H}, \mathrm{brqt}, 1.6)$ & 80.9 & $5.07(1 \mathrm{H}, \mathrm{dd}, 5.0,1.8)$ & 80.8 & $5.17(1 \mathrm{H}, \mathrm{dt}, 5.0,1.6)$ \\
$\mathbf{8}$ & 136.7 & & 82.1 & & 82.1 & \\
$\mathbf{9}$ & 55.4 & $2.99(1 \mathrm{H}, \mathrm{dd}, 6.5,4.9)$ & 51.9 & $2.57(1 \mathrm{H}, \mathrm{dd}, 10.0,7.7)$ & 54.0 & $2.45(1 \mathrm{H}, \mathrm{dd}, 11.1,6.2)$ \\
$\mathbf{1 0}$ & 62.5 & $4.59(1 \mathrm{H}, \mathrm{d}, 13.2)$ & 67.4 & $4.12(1 \mathrm{H}, \mathrm{d}, 11.6)$ & 65.0 & $3.91(1 \mathrm{H}, \mathrm{d}, 11.6)$ \\
& & $4.72(1 \mathrm{H}, \mathrm{d}, 13.2)$ & & $4.38(1 \mathrm{H}, \mathrm{d}, 11.6)$ & & $4.18(1 \mathrm{H}, \mathrm{d}, 11.6)$ \\
$\mathbf{1 1}$ & 172.4 & & 172.5 & & 172.4 & \\
$\mathbf{1 2}$ & 20.7 & $2.09(3 \mathrm{H}, \mathrm{s})$ & 20.7 & $2.09(3 \mathrm{H}, \mathrm{s})$ & 20.7 & $2.09(3 \mathrm{H}, \mathrm{s})$ \\
$\mathbf{1 3}$ & & & 171.8 & & 171.2 & \\
$\mathbf{1 4}$ & & & 21.0 & $2.07(3 \mathrm{H}, \mathrm{s})$ & 21.0 & $2.07(3 \mathrm{H}, \mathrm{s})$
\end{tabular}

\section{Experimental}

\subsection{General}

IR spectra were recorded with a Shimadzu FT-IR-8400S (Shimadzu, France) spectrophotometer. ${ }^{1} \mathrm{H}$ and ${ }^{13} \mathrm{C}-\mathrm{NMR}$ spectra were recorded on a Bruker Avance III 600 spectrometer equipped with a cryoprobe $\left({ }^{1} \mathrm{H}\right.$ at $600 \mathrm{MHz}$ and ${ }^{13} \mathrm{C}$ at $\left.150 \mathrm{MHz}\right)$. 2D NMR experiments were recorded by means of standard Bruker microprograms (Xwin-NMR version 2.1 software TopSpin 3.2). Chemical shifts $(\delta)$ are reported in parts per million (ppm) using the residual solvent signals as secondary reference relatively to TMS $(\delta=0)$, while the coupling constants ( $J$ values) are given in Hertz $(\mathrm{Hz})$. TOF-ESIMS and HR-TOFESIMS spectra were recorded using a Micromass Q-TOF micro instrument (Manchester, UK) equipped with an electrospray source. The samples were introduced by direct infusion in a solution of $\mathrm{MeOH}$ at a rate of $5 \mu \mathrm{L} \mathrm{min}^{-1}$. The optical rotations were measured on a Bellingham \& Stanley ADP 220 polarimeter (Bellingham + Stanley Ltd., United Kingdom). Column chromatography was run on Merck silica gel 60 (70-230 mesh) and gel permeation on Sephadex LH-20 while TLC was carried out on silica gel $\mathrm{GF}_{254}$ pre-coated plates with detection accomplished by spraying with $50 \% \mathrm{H}_{2} \mathrm{SO}_{4}$ followed by heating at $100^{\circ} \mathrm{C}$, or by visual inspection under UV lamp at 254 and $365 \mathrm{~nm}$.

\subsection{Plant material}

The whole plant of B. owariensis was collected at Tsinkop, Menoua Division, West Region of Cameroon, in October 2013. Authentication was done by Mr Victor Nana, a botanist of the 
Cameroon National Herbarium, Yaoundé, where the voucher specimen ( $\left.\mathrm{N}^{\mathrm{o}} 34376 / \mathrm{HNC}\right)$ has been deposited.

\subsection{Extraction and isolation}

The air-dried and plant material $(4 \mathrm{Kg})$ was powdered and extracted at room temperature with methanol $(3 \times 15 \mathrm{~L}, 72 \mathrm{~h})$. The solvent was evaporated under reduced pressure, leaving an extract (110 g). Part of this extract (100 g) was extracted with $n$-hexane yielding $\mathbf{3 0} \mathrm{g}$ fraction after evaporation to dryness. Part of $n$-hexane-soluble fraction (25 g) was subjected to silica gel column chromatography using Hex-EtOAc (9:1 to 1:0) gradient graduated elution. Many fractions of $250 \mathrm{~mL}$ each were collected and combined on the basis of their TLC profiles to give 3 fractions: A, B and C. Fraction B (5.1 g) was purified on silica gel column chromatography using an isochratic eluent system Hex-EtOAc (1:1). Fractions of $10 \mathrm{~mL}$ were collected and combined on the basis of TLC profiles to give 3 sub-fractions $B_{1}, B_{2}$ and $B_{3}$. Sub-fraction $\mathrm{B}_{2}(102 \mathrm{mg})$ was subjected to silica gel column chromatography using HexEtOAc (3:2) as eluent to give compound $\mathbf{1}(8 \mathrm{mg})$ and a mixture of $\mathbf{2}$ and 3. This mixture was combined to sub-fractions $\mathrm{B}_{1}$ and $\mathrm{B}_{3}$ and purified by chromatography on silica gel column chromatography to yield compounds $\mathbf{3}(12 \mathrm{mg})$ and $\mathbf{2}(9 \mathrm{mg})$.

\section{New compounds}

Owariensisone B: Yellowish gum; ${ }^{1} \mathrm{H}$ and ${ }^{13} \mathrm{C}-\mathrm{NMR}$ data, see Table $1 ;[\alpha]_{\mathrm{D}}{ }^{21}-5.2(\mathrm{MeOH} c$ 0.06); IR ( NaCl) $v_{\max }\left(\mathrm{cm}^{-1}\right)$ 3350-3300, 1070, $1040(\mathrm{OH}), 1643(\mathrm{C}=\mathrm{O}), 1605,1580,1520$ (C=C aromatic), $1650(\mathrm{C}-\mathrm{O})$; HR-TOFESIMS (positive ion mode) $\mathrm{m} / \mathrm{z}: 249.0734[\mathrm{M}+\mathrm{Na}]^{+}$ (calcd. for $\mathrm{C}_{11} \mathrm{H}_{14} \mathrm{O}_{5} \mathrm{Na} 249.0739$ ).

Owariensisone $\boldsymbol{C}$ : Yellowish gum; ${ }^{1} \mathrm{H}$ and ${ }^{13} \mathrm{C}-\mathrm{NMR}$ data, see Table $1 ;[\alpha]_{\mathrm{D}}{ }^{21}-20(\mathrm{MeOH} c$ 0.05); IR ( NaCl) $v_{\max }\left(\mathrm{cm}^{-1}\right)$ 3350-3300, 1070, $1040(\mathrm{OH}), 1643(\mathrm{C}=\mathrm{O}), 1605,1580,1520$ (C=C aromatic), $1650(\mathrm{C}-\mathrm{O})$; HR-TOFESIMS (positive ion mode) $\mathrm{m} / \mathrm{z}: 325.0905[\mathrm{M}+\mathrm{Na}]^{+}$ (calcd. for $\mathrm{C}_{13} \mathrm{H}_{18} \mathrm{O}_{8} \mathrm{Na} 325.0899$ ).

Owariensisone D: Yellowish gum; ${ }^{1} \mathrm{H}$ and ${ }^{13} \mathrm{CNMR}$ data, see Table $1 ;[\alpha]_{\mathrm{D}}{ }^{21}-87.5(\mathrm{MeOH} c$ 0.02); IR ( NaCl) $v_{\max }\left(\mathrm{cm}^{-1}\right)$ 3350-3300, 1070, $1040(\mathrm{OH}), 1643(\mathrm{C}=\mathrm{O}), 1605,1580,1520$ $\left(\mathrm{C}=\mathrm{C}\right.$ aromatic), $1650(\mathrm{C}-\mathrm{O})$; HR-TOFESIMS (positive ion mode) $\mathrm{m} / \mathrm{z}: 325.0892[\mathrm{M}+\mathrm{Na}]^{+}$ (calcd. for $\mathrm{C}_{13} \mathrm{H}_{18} \mathrm{O}_{8} \mathrm{Na} 325.0899$ ).

\section{Acknowledgments}

The authors are grateful to the University of Dschang for financing some consumables used in this work, to the "Service Commun d'Analyses" and "Groupe Isolement et Structure", to the "Institut de Chimie Moléculaire de Reims" for the spectroscopic and spectrometric analysis 
on the ESIMS et NMR equipement of the PlAnet Platform. The EU-programme FEDER to the PlAneT CPER project is gratefully acknowledged.

\section{References}

Aluko, B.T., Alli Smith, Y. R., Omoyeni O. A. 2014. Phytochemical analysis and antioxidant activities of ethanolic leaf extract of Brillantaisia patula. World Journal of Pharmaceutical Research 3, 4914-4924.

Asai, T., Hirayama, Y., Fujimoto, Y., 2012. Epi- $\alpha$-bisabolol 6-deoxy- $\beta$-D-gulopyranoside from the glandular trichome exudate of Brillantaisia owariensis. Phytochemistry Letters 5, 376-378.

Callant, P., Storme, P., Van der Eycken, E., Vandewalle, M., 1983. Iridoïds: stereospecific synthesis of functionalized cyclopentanoid intermediates via bicycle [2.2.1] heptanones. Tetrahedron Letters 24, 5797-5800.

Faparusi, F., Bello-Akinosho, M. M., Oyede, R. T., Adewole, A., Bankole, P. O., Ali, F. F., 2012. Phytochemical Screening and Antibacterial Activity of Brillantaisia patula Leaf. Research Journal of Phytochemistry 6, 9-16.

Foning Tebou, P. L., Mabou, F. D., Ngnokam, D., Harakat, D., Voutquenne-Nazabadioko, L., 2016. Owariensisone: a new iridolactone from the whole plant of Brillantaisia owariensis P. Beauv (Acanthaceae). Natural Product Research 134, 1478-1485.

Heine, H., 1963. Flora of West tropical Africa, Vol. 2. Acanthaceae, $2^{\text {nd }}$ edn (ed. By J. Hutchinson and J. M. Dalziel), pp. 391-425. Hepper, F. N. Millbank, London.

Hilgraf, R., Zimmermann, M., Lehmann, L., Tröger, A., Francke, W., 2012. Stereoselective synthesis of trans-fused iridoïd lactones and their identification in the parasitoid wasp Alloxy stavictrix, Part II: Iridomyrmecins. Beilstein Journal of Organic Chemistry 8, 1256-1264.

Kouno, I., Yasuda, I., Mizoshiri, H., Tanaka, T., Marubayashi, N.,Yang, D. M., 1994. Two new iridolactones and their glycosides from the roots of Patrinia scabra. Phytochemistry 37, 467-472.

Lunn, W. H., 1961. Part I: The structure of catalposide. Part II: Carbonium ion formation at the $\mathrm{C}-10$ position in 2,5-seco-A-bisnorcholestane structures. A thesis submitted to the Faculty of graduate studies and research in partial fulfilement of the requirements for the degree of Doctor of Philosophy. McGill University, Montreal P.Q. Canada.PP. 143.

Makambila-Koubemba, M. C., Mbatchi, B., Ardid, D., Gelot, A., Henrion, C., Janisson, R., Abena, A. A., Banzouzi, J. T., 2011. Pharmacological studies of ten medicinal plants used for analgesic purposes in Congo Brazzaville. International Journal of Pharmacology 7, 608-615. 
Mbatchi, S. F., Mbatchi, B., Banzouzi, J. T., Bansimba, T., Nsonde-Ntandou, G. F., Ouamba, J. M., Berry, A., Benoit-Vical, F., 2006. In vitro antiplasmodial activity of 18 plants used in Congo Brazzaville traditional medicine. Journal of Ethnopharmacology 104, 168-174.

Ngbolua, K. N., Benamambote, B. M., Muanda, D. M., Ekutsu, E., Tshibangu, D. S. T., Gbolo, B. Z., Muanyishay, C. L., Basosila, N. B., Bongo, G. N., Robijaona, B., 2013. Ethnobotanical survey and Ecological Study of some Medicinal Plants species traditionally used in the District of Bas-Fleuve (Bas-Congo Province, Democratic Republic of Congo). Research Journal of Chemistry 1, 1-10.

Morota, T., Nishimura, H., Sasaki, H., Chin, M., Sugama, K., Katsuhara, T., Mitsuhashi, H., 1989. Five cyclopentanoid monoterpenes from Rehmannia glutinosa. Phytochemistry 28, 2385-2391.

Sakan, T., Murai, F., Hayashi, Y., Honda, Y., Shono, T., Nakajima, M., Kato, M., 1967. Structure and stereochemistry of boschniakine, boschnialactone and boschnialinic acid, an oxidation product of boschnialactone. Tetrahedron 3, 4635-4652.

Sisido, K., Inomata, K., Kageyema, T., Utimoto, K., 1968. Conformations of iridolactones and the stereochemistry in the syntheses. Journal of Organic Chemistry 33, 3149-3155.

Tanaka, D., Yoshino, T., Kouno, I., Miyashita, M., Irie, H., 1993. Synthesis of monoterpene lactones, (+)-boschnialactone and (+)-isoiridomyrmecin, starting from L-(+)-arabinose. Tetrahedron 49, 10253-10262. 